Relations industrielles

Industrial Relations

\title{
Income Policies in the Light of International Experience : Further Comments
}

\section{La politique des revenus : quelques commentaires}

\section{Adolph Sturmthal}

Volume 23, numéro 2, 1968

URI : https://id.erudit.org/iderudit/027895ar

DOI : https://doi.org/10.7202/027895ar

Aller au sommaire du numéro

Éditeur(s)

Département des relations industrielles de l'Université Laval

ISSN

0034-379X (imprimé)

1703-8138 (numérique)

Découvrir la revue

Citer cet article

Sturmthal, A. (1968). Income Policies in the Light of International Experience : Further Comments. Relations industrielles / Industrial Relations, 23(2), 221-236. https://doi.org/10.7202/027895ar
Résumé de l'article

L'expérience prouve que la politique des revenus ne peut pas être considérée comme un des fondements d'un programme anti-inflationiste. Elle n'est tout au plus qu'un mécanisme auxiliaire de courte période.

Il y a eu beaucoup de littérature sur le concept d'inflation due à la poussée des côtts. Mais, en fait, la motivation à tout ce travail

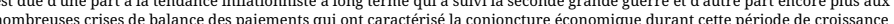
qu'ont constitué les deux dernières décades.

Les questions que l'on peut se poser sur la valeur des théories du « cost push » et le manque de clarté quant aux buts poursuivis

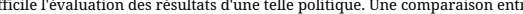
les programmes américains et français illustre ces difficultés.

Il serait bon ici d'insister sur les différences entre les diverses politiques de revenus :

a) disons qu'il semble que notre pays soit particulièrement sensible à l'inflation quoique beaucoup moins au chômage comme la plupart des pays de l'Europe de l'Ouest :

b) la portée de ces politiques peut différer selon qu'elles visent à influencer exclusivement les salaires ou les autres revenus; c) les différences observées peuvent aussi être dues à la multiplicité des méthodes d'approche utilisées.

Résumons les données permettant l'évaluation des diverses politiques de revenu.

TABLEAU I

CHANGEMENTS ANNUELS MOYENS (EN \%) DANS LES COÛTS DE TRAVAIL PAR UNITÉ DE PRODUCTION DANS LINDUSTRIE MANUFACTURIERE $1952-58 \quad 1948-65 \quad 1952-58 \quad 1948-65$

Allemagne $0.1 .8 \quad 3.2 \quad$ Irlande $\quad 1.9 \quad 2.3$

$\begin{array}{llllll}\text { Autriche } & 0.7 & 2.7 & \text { Italie } & -1.8 & 2.6\end{array}$

Belgique $\quad-\quad 0.4 \quad$ Norvège $\quad 1.4 \quad 1.4$

$\begin{array}{lrrrr}\text { Danemark } & 2.0 & 3.9 & \text { Royaume Uni } 3.6 & 2.3\end{array}$

Etats-Unis $1.20-0.8$ Suèle $120-20$

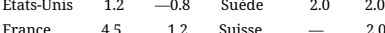

France 4.51 .2

Nous pouvons, à partir de ces chiffres, dégager un certain nombre de conclusions :

a) l'efficacité de la politique des revenus semble s'être atténuée avec le temps ;

b) les restrictions ont perdu de leur efficacité entre la table de négociation et l'atelier

c) l'effet destructeur du « wage drift "sur la politique des revenus est quelque peu incertain

d) l'expérience ne démontre pas que les pays avec des politiques de revenus ont mieux réussi que les autres.

Plusieurs politiques de revenus se sont servies de différentes façons de la productivité comme unité de mesure dans la

détermination des aurmentations de salaires permises. Supposant l'élimination dans les différences d'utilisation de cette mesure, les implications possibles de son utilité ont certaines significations.

a) La première alternative est celle de l'économie concertée. Mais cela ne vaut pas à l'infini.

b) l'action politique syndicale est une autre alternative.

La politique des revenus traite d'un des problèmes fondamentaux d'une société de plein emploi, à savoir sa tendance inflationiste

Après considération des diverses expériences à travers le monde, il reste que le principal problème de ce moyen d'enrayer endance à considérer la politique des revenus dans une perspective de courte période a plutôt été défavorable à la découverte d'une solution.

Elaborons quelque peu :

a) il y a eu, dans le domaine des restrictions de salaires et de prix un divorce entre l'idéologie et l'action :

b) les politiques de revenus représentent un retour aux méthodes dirigistes des années '30;

c) on ignore l'effet en longue période de la politique des revenus sur la productivité

Il semble donc que nous avons traditionnellement considéré notre société de plein emploi de longue période simplement comme une société traditionnelle exempte de chômage substantiel à long terme. Nous constatons de plus en plus que l'absence d'emploi l'absence d'une politique de revenus l'existence du plein emploi de longue période a radicalement changé l'attitude des syndicas et des employeurs.
Tous droits réservés (C) Département des relations industrielles de l'Université Laval, 1968
Ce document est protégé par la loi sur le droit d'auteur. L’utilisation des services d'Érudit (y compris la reproduction) est assujettie à sa politique d'utilisation que vous pouvez consulter en ligne.

https://apropos.erudit.org/fr/usagers/politique-dutilisation/ 


\title{
Income Policies and International Experience : Further Comments
}

\author{
Adolf Sturmthal
}

It remains that the main problem of an incomes policy as a mean of restraining inflation in a full employment economy is that of the long run. It is, I believe, fair to point out that this problem has hardly been tackled so far and that the tendency to look at incomes policy in the light of temporary emergencies has blocked rather than opened the road to a solution.

\section{Introduction}

The recent devaluation of the pound Sterling has put increased emphasis on the problems created by the famous uneasy triangle described by the London Economist in 1952 of full employment, price stability, and free collective bargaining. In an earlier paper, I have attempted to present a first and tentative evaluation of the European experience in that general area. Without much satisfaction, indeed with a good deal of regret, I have to point out that events since that earlier paper was written have confirmed my pessimistic conclusion. Incomes policy is not a main pillar of an anti-inflationary policy. At the best it is a temporary and subsidiary device. In most cases, even within these limis, it cannot be expected to produce totally or even highly satisfactory results.

\section{The Concept of "Cost-Push"}

The concept of cost or supply inflation (" cost-push» as distinguished from "demand-pull ») has a long history. As Bronfenbrenner and Holzman, in their
STURMTHAL, ADOLF, Ph.D. (Economics) professor of Industrial Relations at Columbia University; lecturer in International Trade Unionism at Roosevelt College; author of many books on trade unions and collective bargaining at the international level 
- Survey of Inflation Theory $>$, point out, cost-inflation reasoning underlay, for example, the various Statutes of Laborers which followed the medieval Black Death. * Special reference to wageinflation as a concomitant of full employment was made in the Beveridge Report which, in effect, anticipating the London Economist, suggested compulsory arbitration, thus eliminating free collective bargaining from the ill-fated triangle. Since then, the literature on costpush as distinguished from demand-pull inflation or combined with it has become so voluminous that the Bronfenbrenner-Holzman survey just quoted contains a bibliography of no less than 183 items up to about 1963 - including, it is true, thanks to the linguistic versatility of one of the authors, items in French and Japanese. Considerable intellectual impetus was given to the cost-push theory by the celebrated study of A. W. Phillips on . The Relation between Unemployment and the Rate of Change of Money Wage Rates in the United Kingdom, 1862-1957 * " and the lengthy discussion following this article. The practical motivation for a good deal of the work was provided partly by the long-term inflationary trend in the Western world following World War II, but even more by the series of balance-of-payments crises which dot the economic landscape during the period of growth and super-growth in the last two decades. ${ }^{3}$

\section{The Differences in Objectives}

There is no reason to doubt that inflationary developments can be set off by events on the supply side as well as those on the demand side. What may be questioned is whether the prevailing cost-push theories have produced more than a list of a set of conditions without which cost-push inflation would be impossible rather than an intellectually satisfactory explanation of the force or forces that unleash that process

(1) In Surveys of Economic Theory - Money, Interest, and Welfare (New York: St. Martin's Press, 1965), p. 64.

(2) Economica, November 1958, pp. 283-99.

(3) There has been from time to time mutual incompatibility between full employment and an adequate balance of payments, in the sense that balance of payments difficulties have prevented the achievement or maintenance of full or over-full employment. Contrary to what Professor Hicks (J.R. Hicks : a Economic Foundations of Wage Policy , Economic Journal, LXV, September 1955, p. 391) said, the world is not on a labor standard, but rather on some kind of export-price standard, modified by international capital movements. 
on the supply side and determine its scope and duration. This, however, is a large topic by itself and we shall leave it at this point. ${ }^{*}$

Questions of this kind as well as a certain lack of clarity about the purposes of an incomes policy make for some difficulty in evaluating the results of the latter. Clearly, different evaluations might be obtained according to whether the objective is, for instance,

a) price stability (in terms of some index of wholesale, or retail prices or cost-of-living); or

b) price competitiveness of exported goods and services; or

c) a balance of payments equilibrium defined in some way.

In practice the objectives are frequently mixed. Thus the United States experiment with wage-price guideposts was stated in terms of objective (a), but also of (b) and (c), and sometimes objective (a) was described as a condition for meeting objectives (b) and (c). The well-known French report on Incomes Policy ${ }^{5}$ points out that recessions in postwar France were the result s not of spontaneous fluctuations in the demand, but rather of the obligation of public authorities to restrict credit and budget expenditures in order to counteract the external deficit, which itself followed from an excessively rapid rise of domestic prices. However, shortly after this, the Report refers to the stabilization plan of September 12,1963, which arose without balance of payments crisis, while France possessed large reserves of foreign exchange, with the primary objective of preventing an excessively rapid rise of domestic prices. The objectives of incomes policy may thus not only differ from country to country, but also from time to time.

There is, of course, a fairly close interrelationship among these objectives and between them and another major objective of economic policy - that of economic growth. A detailed analysis lies beyond

(4) E.g., the statistical evidence suggesting significant relationships between wage increases and profit margins for the United States - but not for the United Kingdom - does not * explain ${ }^{*}$ in any sense why wage increases must lead to price increases rather than a reduction of profits. Nor do they explain the conditions giving rise to the large profits so that the hypothesis cannot be rejected that it is the latter rather than the wage increases which set in motion the inflationary process.

(5) Rapport sur la politique des revenus établi à la suite de la Conférence des revenus > (octobre 1963 - janvier 1964), présenté par M. Pierre Massé, February 13, 1964, La Documentation Frangaise, 1964, p. 5 . 
the purpose of this paper, but it deserves pointing out that in most cases trade-offs at the margin between competitive objectives may be involved. Thus some trade-off may be made between economic growth and price stability, price stability and industrial unrest, or economic growth and external deficits so that considerations of domestic politics, foreign policy and the stability of exchange rates enter the picture. Domestic politics may determine the maximum acceptable rate of unemployment, of inflation and of social conflict; foreign policy the maximum rate of curtailment (or the minimum rate of expansion) of foreign commitments, as well as permissible rates of currency devaluation, etc.

Thus, it would appear that this country is particularly sensitive to inflation and somewhat less sensitive than most countries in Western Europe to unemployment. Industrial conflict is accepted more freely in this country than, perhaps in Germany, and so on. Empirically, this is difficult to determine without getting into some degree of circular reasoning: we might read tolerance of inflation into data on relative inflation and then explain inflation out of tolerance for it, etc. For an anthropologist or political scientist, cross-cultural comparisons in this field might be of considerable interest.

Another distinction among incomes policies may be made according to the scope of these policies - i.e., whether they aim at influencing wages alone or other incomes as well (directly or, more frequently, indirectly by way of influence on prices or price changes).

Thirdly, incomes policies may be pursued by a variety of methods which in turn may be classified in different ways. One such classification may be based upon the degree of coercion involved ranging from what the Germans call « soul massage » to strict enforcement by controls and courts.

Further distinctions could be made according to the degree of involvement of unions and employers associations in the process, the relationship between incomes policies and other economic policies, etc.

In the absence of clearly stated objectives and given their interrelationship, I have attempted to evaluate the policies pursued in different countries in terms of a single criterion - changes in labor costs. Other criteria - e.g., stability of the price level however defined or especially stable weighted price averages of domestically produced goods and 
services - are of course equally applicable or, from some points of view, even more meaningful. Unit labor costs, however, are significant for many purposes and are statistically reasonably well defined and available.

\section{The Evaluation of Incomes Policies}

The data for the evaluation of various incomes policies have been presented in a previous paper. Briefly summarized, they are as follows:

TABLE 1

Average Annual Changes (in per cents) of Labor Costs (Earnings) PER Unit OF OUtPut in Manufacturing

$1952-58 \quad 1948-65$

$\begin{array}{lrr}\text { Austria } & 0.7 & 2.7 \\ \text { Belgium } & - & 0.4 \\ \text { Denmark } & 2.0 & 3.9 \\ \text { France } & 4.5 & 3.2 \\ \text { West Germany } & 1.8 & 3.2 \\ \text { Ireland } & 1.9 & 2.3 \\ \text { Italy } & -1.8 & 2.6\end{array}$

$1952-58 \quad 1948-65$

$3.2 \quad 3.0$

$1.4 \quad 1.4$

$2.0 \quad 2.0$

$-\quad 2.0$

$3.6 \quad 2.3$

$1.2-0.8$

Source: C.T. Saunders, ECE, « Macro-Economic Aspects of Incomes Policy ». Paper presented in October 1966 at a Symposium on the Labor Market and Inflation, organized by the International Institute for Labor Studies, Geneva. The papers and proceedings of this Symposium are to be published in book form.

Of the 13 countries listed, five - Austria, Denmark, Netherlands, Norway, Sweden - are countries with incomes policies; eight - Belgium, France, West Germany, Ireland, Italy, Switzerland, the United Kingdom and the United States - are classified as countries without an incomes policy during all or most of the two periods considered (1952-58; 1958-65). There may be some argument about some of the classifications. Thus the Scandinavian countries have practiced, most of the time, an incomes policy administered by the partners to collective bargaining based upon their highly centralized bargaining systems. I have included them in the list of countries with income policies even though the government plays only a subsidiary role in income determination. The United States and the United Kingdom, for part of the second period had their guideposts and the National Board for Prices and Incomes - the United States since 1962, the United Kingdom effectively since 1965. I have included both among the countries without policy, taking into account the greater part of the period under consideration. 
Some conclusions that are suggested by these data are:

a) The effectiveness of incomes policies seems to have diminished over time, but this may be due to increasing inflationary pressures rather than the progressive decline in the impact of the policy on earnings.

b) Restraint has worked best at the highest levels of employers' and workers' organizations and seems to have lost some of its effectiveness along the way from the bargaining table to the workshop. Hence the phenomenon of wage drift, the discrepancy between contract and effective rates.

c) The extent to which wage drift has defeated incomes policy is somewhat dubious. There seems to be some, though not very close, relationship between wage drift and inflationary pressure - not enough to make restraint on negotiated wage increases completely irrelevant, but sufficient to reduce the effectiveness of incomes policy to situations with a high rate of increase of labor costs (approximately 2.5 per cent per annum).

d) The evidence does not indicate that countries with incomes policies have done any better than those without. However, the number of cases is so small, the diversity of situations so tremendous (e.g., impact of foreign trade, differences in collective bargaining systems, currency devaluations), the limitation of the data to manufacturing, so important a qualification that one hesitates to draw farreaching conclusions. Perhaps all that can prudently be said is that the case for the effectiveness of incomes policies has not been proven.

e) It should be understood that this conclusion holds even if the criterion of success or failure is not set at perfect equivalence between the rate of increase of effective incomes and the target rate. For the data indicate that countries with (formal or informal) incomes policies do not fare any better than those without. The limitations on this conclusion are the same as those just mentioned.

\section{The Implications}

Perhaps more interesting are some of the implications of incomes policies and the discussions accompanying the introduction of such 
policies. Many incomes policies have used productivity in some ways as the main yardstick in the determination of permissible wage increases. ${ }^{6}$ Assuming that all divergencies about the measurement of productivity changes can be settled, the alternative implications of the use of such a yardstick are of considerable significance.

(a) One alternative is the a économie concertée ", or * consensus *, an agreement on the maintenance of the existing income shares. ${ }^{7}$ Such an agreement is unlikely to be forthcoming, certainly not for the long run. It is conceivable, indeed likely, that a temporary agreement of this kind could be concluded, say - for the duration of a national emergency, such as a war or an overwhelming natural disaster. Nothing, however, justifies the expectation that such an agreement would be eternal or even long-lasting. ${ }^{8}$

Sometimes, acceptance of an incomes policy is suggested in the light of the consideration that money wage increases going beyond productivity increases are self-defeating. This is surely incorrect where c competitive sectional bargaining " prevails and - as a result of various lags - may be incorrect even for highly centralized national wage bargains. If it were true or if it were accepted as truth or if the assumptions underlying the économie concertée were to be imposed upon the collective bargaining system, then the alternative (b) would arise.

(b) If collective bargaining cannot be used as an instrument for a change in the distribution of the national income, then it is more likely that labor would be induced to employ other methods for the purpose.

(6) In other cases - e.g., Sweden and the Netherlands - estimates of a allowable wage increases have been based upon forecasts of output changes during the coming year. The United Kingdom shifted from a long-term productivity trend to a projected figure based on forecasts of the National Economic Development Council.

(7) The absence of such an agreement in the United States where the guideposts were discussed neither in Congress nor with labor and management, did not present too much of a problem at first, particularly in early years of President Johnson's term of office. Later, this proved to be one of the decisive weaknesses of the policy.

(8) Pierre Massé, former Commissaire au Plan, has expressed the somewhat surprising hope that the joint efforts of neutral experts and representatives of interest groups within the Study Center of Incomes and Costs (CERC) set up in April 1966 would produce some from of a social contract embodying a \& conscience concerning the future $\gg$. It is too early to judge the results of the work of CERC. In the case of Britain, a temporary and reluctant consensus seems to have been reestablished as a result of the devaluation of the pound Sterling, but this, too, is an carly and uncertain impression. 
Among these, political action would be the most likely candidate. Stymied in its attempt to use the bargaining process for one of its main objectives, labor would shift a good deal of its effort into the arena of politics: This may be good or bad, according to one's predilections. What matters is simply to recognize the implications of what one is doing. Incomes policy in general would most often tend to emphasize the political concerns of labor. An incomes policy based ip ion an unchanging distribution of the national income would undoubtedly reenforce that trend.

This evolution would become even more likely if a given incomes policy were unable or unwilling to prevent other changes in income distribution while holding labor's share constant. Thus a transfer into corporate profits from - say - returns on smaller enterprises would make an incomes policy morally hard to defend and would invite shifts into the political arena if the collective bargaining process cannot be used as an instrument of change in the distribution. ${ }^{9}$

\section{Some Deeper Issues}

This consideration leads one into an examination of still deeper lying issues. Incomes policies, in their current fashion, were designed to deal primarily with one of the basic problems of a full employment society, namely its built-in inflationary trend. The question may be asked whether the policies that have been proposed are designed to deal with a long-term situation or with temporary emergencies. In the latter sense, experiments have been made in various situations: in Great Britain, the 1948-51 attempt to restrain wage increases, the 1939-47 wage policy understanding; counterparts can be found in the United States, in Sweden, and elsewhere. All these had in common their intentional transitional character. As such they were fairly successful devices for slowing down processes. ${ }^{10}$ In most cases, the effectiveness of the restraint tended to diminish as time went on, and the termination of

(9) As against this, the argument can be advanced that labor's share has been constant under free collective bargaining. This may be so, but politically, there is a world of difference between the result of the operations of the market and a formal acceptance of the status quo. Needless to say, stability of labor's share does not mean stable share for every single group or for organized labor as a whole.

(10) See Clark Kerr's paper on "Governmental Wage Restraints : Their Limits and Uses in a Mobilized Economy ", American Economic Review, Vol. XILII, No. 2, May 1952. Kerr discusses the relative effectiveness of restraints under various assumptions about the degree of urgency of the emergency. 
the experiment usually occurred in fact before it was officially abandoned.

This view of incomes policies seems to have been lost. With full employment in most Western countries a permanent and highest priority objective of economic policy and an almost uninterrupted fact for a decade and a half in Western Europe, the notion that incomes policies are temporary emergency measures appears to have given way to a new approach. This regards both full employment and incomes policies designed to restrain inflationary cost developments as permanent features of a modern economic landscape. An intermediate approach views both full employment and inflationary pressure as long-term, but intermittent phenomena: inflationary full employment periods interrupted from time to time by * lapses » from full employment accompanied by declines in earnings, stable wage rates, and relative price stability. Given the downward inertness of wage rates and the relatively greater difficulty of obtaining price decreases (as against the prevention of price increases), this last view would merely hold out the hope of a lesser rate of inflation paid for by higher average levels of unemployment over time - a kind of hiccupping-inflation accompanied by hiccupping unemployment.

It thus remains that the main problem of an incomes policy as a means of restraining inflation in a full employment economy is that of the long run. It is, I believe, fair to point out that this problem has hardly been tackled so far and that the tendency to look at incomes policy in the light of temporary emergencies has blocked rather than opened the road to a solution. Let me elaborate on this.

(a) In the area of price and wage restraint, the divorce of ideology from action has been most obvious. I cannot do better than quote John Kenneth Galbraith, even though my own conclusions as to how to proceed, differ considerably from his. He says:

On occasions of public ceremony, businessmen and numerous union leaders must still proclaim their commitment to the free market. And likewise economists. It is hard to turn from these liturgical exercises to a consideration of practical measures for insuring that the guideposts -will be observed. In the thirties, although the commitment of economists to the canons of sound finance was still strong, a minority accepted the implications of the Keynesian system and proceeded to work out its application to practical fiscal policy. Though radical this was not wholly disreputable. To work on methods of wage and price control is not reputable. Only after a scholar is in public office is the 
ban lifted. And then he is careful to speak not of control but (as frequently here) of restraint. The amenability of the corporations and unions to control - ideology to the contrary - means that it need not be very strong. But it is hard to take purely hortatory enforcement very seriously. ${ }^{11}$

And in a final blow, he quotes Paul Samuelson:

- These guideposts... do not have the force of law; the scowls by the President... cannot solve the dilemmas of full employment and price stability. ${ }^{12}$

(b) Incomes policies represent a return, concealed as it may be, to the methods of the \& dirigisme > of the Thirties. Instead of continuing along the lines of the more sophisticated approach - changes in the demand and supply schedules - we are returning to attempts to control directly the outcome of the market. This, I submit, is a loss, not only in sophistication, but also in effectiveness.

(c) We do not know very much about the long-run impact of incomes policies on productivity. In our concern with the reverse relationship, we have neglected - again as a long-run proposition - the influence that incomes policies may have upon the allocation of labor, its training, etc. The conflict that may exist between the requirements -..- in terms of wage structure and avoidance of industrial conflict - of rapid economic growth and of price stability, has hardly been examined. ${ }^{18}$

In particular, we have hardly begun to examine the possible impact of incomes policies on the allocation of resources in the long run. This involves two different sets of questions: the substitution of capital for labor and the substitution of one type of labor for another.

To begin with the latter, it has become fashionable to point out that clianges in wage differentials are not necessary to allocate different kinds

(11) John Kenneth Galbratth, The New Industrial State (Boston : Houghton Mifflin, 1967), p. 258.

(12) Paul A. Samuelson, Economics, Sixth Edition (New York : McGraw, 1964), p. 792 .

(13) It is hazardous to make a medium-term appraisal of the 1966-67 freeze, because if the demand restrictions affect the long term productivity growth rate, there could be a serious offset to any gain from a more moderate growth in incomes. \ John G. Corina's * Can an Incomes Policy Be Administered? * Paper prepared for the Third World Congress, IRRA, September 1967. See also W.R.C. Keeler, "The Relationship of Plant Productivity Agreements to Incomes Policy *, British Journal of Industrial Relations, Vol. V, No. 1, March 1967. 
of labor. ${ }^{14}$ However, whether this conclusion holds for every occupational group is an open question event assuming that it holds in the aggregate. In order to be true for all occupational groups (and in every labor market taken separately) all supply and demand elasticities of occupational groups would have to be of the same general shape - a somewhat unlikely proposition.

The indifference toward labor supply elasticity in the OECD study contrasts sharply with the exactly opposite view advanced by Kindleberger. ${ }^{15}$ According to him, the great secret of the long European boom has been the unusually high elasticity of labor supply in Western Europe. Once again, I would prefer to speak of the supply elasticity of particular occupational groups; in this case, the key may have been in the high elasticity of the supply of common labor, the increase in demand for higher skills and the ability of formerly unskilled workers to move up into better-paying jobs for which they represented a highly elastic supply. ${ }^{16}$ Thus the immigration of common labor made for high supply elasticities for both low-paying and medium-paying jobs. To generalize this situation is, however, inadmissible in terms of both time and place.

As to the substitution of capital for labor, attempts to hold wages down would affect substitution rates only if the simultaneous attempt to hold down prices were unsuccessful or less successful. ${ }^{17}$

\section{Conclusions}

Still more fundamental, it seems to me, is the fact that we have regarded a long-term full employment society simply as our traditional society minus substantial long-term unemployment. Only gradually

(14) See in particular the OECD study of wages and labor mobility. It is, however, possible to interpret the data presented in that study as suggesting the opposite conclusion.

15 Charles P. Kindleberger, Europe's Postwar Growth (Cambridge, Mass.: Harvard University Press, 1967). This view finds support in Angus Maddison's study of Western Europe.

(16) In the European case, where manufacturing employment is still expanding, the "relative wage signal *, to use Bob Raimon's expression, was pointing in the right direction.

(17.) A successful price policy, however, might, if productivity is used as a guidepost, require price decreases. In that case, marginal substitution rates might be changed, not by economic rationality, but by the relative degrees of effectiveness of incomes policies. The economic structure would adjust to the latter and post hoc * justify * the politically determined solution. 
are we becoming aware of the fact that the absence of substantial longte:rm employment may affect the character of some of our basic institutions.

Since the work of A. W. Phillips ${ }^{18}$ we are all aware of the close though perhaps kinked connection between the level of unemployment and the rate of change of money wage rates. The search for a critical level of unemployment at which inflationary wage developments could be held within acceptable limits has been extensive though its results have been uncertain. A part of the reason for this uncertainty lies in the lack of a clear distinction between short-run and long-run. Levels of unemployment or rates of wage-cost inflation that may be acceptable in the short run may be intolerable as long-run phenomena and viceversa.

More important still : Unions and businesses might be prepared to accept restraints on their wage and price policies for short-run emergencies which might be intolerable for them in the long run. They might be able to carry out a policy of restraint for a given period, but might find it impossible for an indefinite length of time. Indeed, it is difficult to see how unions and businesses could operate over the long run without a profound change in their character if the restraints of an incomes policy were to be imposed upon them permanently. It is quite possible that unions could continue to exist within such a framework, but they would hardly be unions of the kind that now exists. Undoubtedly, private enterprise could in some ways adapt to the requirements of an incomes policy, but it would in the process change its character radically.

Admittedly, there is nothing sacred about either institution and it is fairly obvious that even in the absence of an incomes policy unions and businesses are being changed radically by the existence of long-term full employment. There may be good reasons for willing acceptance of the further and still more radical transformation which an incomes policy would impose - with varying degrees of harshness - upon both unions and businesses. What I question is whether such changes should be

18 A.W. Phulips : "The Relation between Unemployment and the Rate of Change of Money Wage Rates in the United Kingdom, 1852-1957 », Economica, $\mathrm{XXV}$, November 1958. This has been followed by a prolonged discussion. A survey of the latter is presented in George L. Perry : Unemployment, Money Wage Rates, and Inflation (Cambridge, Mass. : M.I.T. Press, 1966). 
made - as it were - incidentally, as by-products of policies designed to cope with an essentially temporary emergency.

This question takes on even greater significance in view of the fact that it is doubtful whether incomes policies can do much more than attempt to suppress the results of disequilibria on the labor and product markets without affecting the disequilibria themselves. Not too much, I suspect, should be made of this argument for the short run since neither labor nor most product markets approach the state of perfect markets and since administered prices prevail as a result of oligopolistic institutions. But once again: over the long run, the term * suppressed inflation $\gg$ takes on reality, even in imperfect markets and in the presence of oligopoly. The distortions produced by concealed inflation are likely to become increasingly significant as the time span grows over which we consider the phenomenon.

Moreover, to the degree that these consequences are not visible to the naked eye, the suppression of inflation makes it easier to avoid tackling the real problems underlying the process of wage-inflation, first among them the lack of elasticity in the supply of labor. Two issues in particular must be squarely confronted.

1. As was stated earlier, trade-offs among various objectives of economic policy are unavoidable. One task of economic policy then is first of all to make choices as rational as they can be, by pointing out the trade-offs that are possible and necessary. This is based upon the - perhaps utopian - belief that rational and consious choices are better than incidental and emotional ones. ${ }^{19}$

2. Another major tool-objective of economic policy is that of making choices easier by reducing - as it were - the opportunity costs. Raising the level of tolerable inflation, for instance, by compensating, partly or fully, some of its victims - reducing industrial conflict by providing better machinery for its settlement - reducing inflationary pressures by increasing productivity or making supply schedules of production factors more elastic - facilitating international business under fluctuating exchange rates or wider gold points - all these and many

(19) For this reason as well as others, some degree of price increase has been accepted by economic policy-makers in several countries, as for example in the Fifth Plan in France, the Report for 1966 of the «Three Wise Men » in Denmark, and the 1965 Report of the German Committee of Economic Experts. 
more may be called upon to assists in making trade-offs easier to accept. The measures required to this end, running from education and retraining to modifications of union organization, involve much further-reaching institutional changes than the term * higher elasticity of labor " would lead one to expect. Still, all in all, what we would be aiming at is an accommodation among competitive objectives rather than a clear-cut solution of a given problem.

\section{LA POLITIQUE DES REVENUS: QUELQUES COMMENTAIRES}

L'expérience prouve que la politique des revenus ne peut pas être considérée comme un des fondements d'un programme anti-inflationiste. Elle n'est tout au plus qu'un mécanisme auxiliaire de courte période.

II y a eu beaucoup de littérature sur le concept d'inflation due à la poussée des coûts. Mais, en fait, la motivation à tout ce travail est due d'une part à la tendance inflationniste a long terme qui a suivi la seconde grande guerre et d'autre part encore plus aux nombreuses crises de balance des paiements qui ont caractérisé la conjoncture économique durant cette période de croissance qu'ont constitué les deux dernières décades.

Les questions que l'on peut se poser sur la valeur des théories du a cost push * et le manque de clarté quant aux buts poursuivis par une politique des revenus rendent encore plus difficile l'évaluation des résultats d'une telle politique. Une comparaison entre les programmes américains et français illustre ces difficultés. revenus :

Il serait bon ici d'insister sur les différences entre les diverses politiques de

a) disons qu'il semble que notre pays soit particulièrement sensible à l'inflation quoique beaucoup moins au chômage comme la plupart des pays de l'Europe de l'Ouest;

b) la portée de ces politiques peut différer selon qu'elles visent à influencer exclusivement les salaines ou les autres revenus ;

c) les différences observées peuvent aussi être dues à la multiplicité des méthodes d'approche utilisées.

Résumons les données permettant l'évaluation des diverses politiques de revenu. 


\section{TABLEAU I}

Changements annuels moyens (en \%) dans les coûts de travar. par untre DE PRODUCTION DANS L'INDUSTRUE MaNUFACTURTìe

$$
1952-58 \quad 1948-65
$$

$1952-58 \quad 1948-65$

\begin{tabular}{|c|c|c|c|c|c|}
\hline Allemagne $\mathrm{O}$. & 1.8 & 3.2 & Irlande & 1.9 & 2.3 \\
\hline Autriche & 0.7 & 2.7 & Italie & -1.8 & 2.6 \\
\hline Belgique & - & 0.4 & Norvège & 1.4 & 1.4 \\
\hline Danemark & 2.0 & 3.9 & Royaume Uni & 3.6 & 2.3 \\
\hline Etats-Unis & 1.2 & -0.8 & Suede & 2.0 & 2.0 \\
\hline France & 4.5 & 1.2 & Suisse & - & 2.0 \\
\hline Hollande & 3.2 & 3.0 & & & \\
\hline
\end{tabular}

Nous pouvons, à partir de ces chiffres, dégager un certain nombre de conclusions :

a) l'efficacité de la politique des revenus semble s'être atténúé avec le temps ;

b) les restrictions ont perdu de leur efficacité entre la table de négociation et l'atelier;

c) l'effet destructeur du * wage drift » sur la politique des revenus est quelque peu incertain;

d) l'expérience ne démontre pas que les pays avec des politiques de revenus ont mieux réussi que les autres.

Plusieurs politiques de revenus se sont servies de différentes façons de la productivité comme unité de mesure dans la détermination des augmentations de salaires permises. Supposant l'élimination dans les différences d'utilisation de cette mesure, les implications possibles de son utilité ont certaines significations.

a) La première alternative est celle de l'économie concertée. Mais cela ne vaut pas \& l'infini.

b) Yaction politique syndicale est une autre alternative.

La politique des revenus traite d'un des problèmes fondamentaux d'une société de plein emploi, à savoir sa tendance inflationiste interne.

Après considération des diverses expériences à travers le monde, il reste que le principal problème de ce moyen d'enrayer l'inflation dans une economie de plein emploi est celui de la longue période. Cette difficulté n'a pas encore été surmontée et la tendance à considérer la politique des revenus dans une perspective de courte période a plutôt été défavorable à la découverte d'une solution.

Elaborons quelque peu :

a) il y a eu, dans le domaine des restrictions de salaires et de prix, un divorce entre l'idéologie et l'action : 
b) les politiques de revenus représentent un retour aux méthodes dirigistes des années ' 30 ;

c) on ignore l'effet en longue période de la politique des revenus sur la productivité

Il semble donc que nous avons traditionnellement considéré notre société de plein emploi de longue période simplement comme une société traditionnelle exempte de chômage substantiel à long terme. Nous constatons de plus en plus que l'absence d'emploi substantiel de longue période peut affecter certaines des bases de nos institutions. Il n'est aucune institution sacrée et même en l'absence d'une politique de revenus l'existence du plein emploi de longue période a radicalement changé l'attitude des syndicats et des employeurs.

\section{SOCIALISATION ET RELATIONS INDUSTRIELLES}

La socialisation: caractère et signification (GERARD DION). L'entreprise privée face d la socialisation (RAYMOND GERIN). Le syndicalisme en contexte socialisée: fonctions et responsabilités nouvelles (LOUIS-MARIE TREMBLAY). Le rôle de l'Etat en relations du travail - essai de réévaluation (JEAN-REAL CARDIN). L'Etat-employeur et la fonction publique (S.J. FRANKEL). Discussion (ALBERT GINGRAS, YVON CHARTRAND, MICHEL HARRISON). La négociation collective dans les secteurs privés subventionnés par l'Etat. Point de vue patronal (PAUL DESROCHERS). Point de vue syndical (JACQUES ARCHAMBAULT). Discussion (GILLES GAUDREAULT, LEOPOLD GARANT, J.-R. GAUTHIER). Planification, entreprise privée et syndicalisme libre (PAUL NORMANDEAU).

$$
1 \text { volume, } 188 \text { pages - Prix: } \$ 3.00
$$

LES PRESSES DE L'UNIVERSITE LAVAL 